\title{
PENGARUH STRATEGI PEMASARAN TERHADAP KEPUASAN DAN KEPUTUSAN PEMBELIAN PRODUK USAHA KECIL MENENGAH (UKM) 310 DI MAKASSAR
}

\author{
Nur Naninsih \\ STIE Amkop Makassar (nurnaninsihcani@gmail.com) \\ Hardiyono \\ STIE Amkop Makassar (dyonsri@gmail.com)
}

\begin{abstract}
ABSTRAK
Penelitian ini bertujuan mengetahui pengaruh strategi pemasaran terhadap kepuasan dan keputusan pembelian produk usaha kecil menengah (UKM) 310 di Makassar. Penelitian ini menggunakan penelitian kuantitatif. Penelitian kuantitatif adalah suatu proses menemukan pengetahuan yang menggunakan data berupa angka sebagai alat menganalisis keterangan mengenai apa yang ingin diketahui. Hasil dari penelitian ini menemukan bahwa secara parsial strategi pemasaran berpengaruh positif dan signifikan terhadap kepuasan pembeli, strategi pemasaran berpengaruh positif dan signifikan terhadap keputusan pembelian, serta kepuasan yang berpengaruh positif dan signifikan terhadap keputusan pembelian. Adapun pengaruh tidak langsung menunjukkan bahwa strategi pemasaran berpengaruh positif dan signifikan terhadap keputusan pembelian melalui kepuasan.
\end{abstract}

Kata Kunci: strategi pemasaran, kepuasan, keputusan pembelian

\begin{abstract}
This study aims to determine the effect of marketing strategies on satisfaction and purchasing decisions for small and medium enterprises (UKM) 310 in Makassar. This research uses quantitative research. Quantitative research is a process of finding knowledge that uses data in the form of numbers as a tool to analyze information about what you want to know. The results of this study found that partially marketing strategies have a positive and significant effect on buyer satisfaction, marketing strategies have a positive and significant effect on purchasing decisions, and satisfaction has a positive and significant effect on purchasing decisions. The indirect influence shows that marketing strategies have a positive and significant effect on purchasing decisions through satisfaction.
\end{abstract}

Keywords: marketing strategies, satisfaction, purchasing decisions

\section{PENDAHULUAN}

Pengembangan Usaha Kecil Menengah (UKM) di Indonesia menjadi bagian dari prioritas dalam pembangunan ekonomi nasional. Hal tersebut terjadi karena usaha tersebut UKM merupakan tulang punggung sistem ekonomi kerakyatan yang tidak hanya ditujukan untuk mengurangi masalah kesenjangan antar golongan, pendapatan 
dan antar pelaku usaha, ataupun pengentasan kemiskinan dan penyerapan tenaga kerja. Sealain dari itu, perkembangan UKM mampu memperluas basis ekonomi dan dapat memberikan konstribusi yang signifikan dalam mempercepat perubahan struktural, yaitu meningkatnya perekonomian daerah dan ketahanan ekonomi nasional.

Para pelaku UKM perlu memperhatikan strategi pemasaran dalam menjalankan bisnis agar dapat berkembang ditengah persainga bisnis yang semakin meningkat dimana pada era teknologi saat ini, hamper semua produk dapat dilihat dari internet, baik berupa tampilan, resep, ataupun cara membuat produk. Husein Umar dalam penelitian Padhil et.al (2018) mengemukakan bahwa kondisi pertumbuhan bisnis dapat dilihat dari bermunculanya perusahaan-perusahaan dengan produk yang sejenis sebagai pesaing, sehingga akan terjadi persaingan yang semakin ketat memperebutkan pangsa pasar. Pemilik usaha kecil menengah (UKM) hendaknya memiliki strategi pemasaran yang terbaik untuk menciptakan kepuasan pembeli untuk mendukung keputusan pembelian.

Pengertian Strategi Pemasaran menurut Sofjan Assauri (2013:15) yakni serangkaian tujuan dan sasaran, kebijakan dan aturan yang memberi arah kepada usaha-usaha pemasaran perusahaan dari waktu ke waktu, pada masing-masing tingkatan dan acuan serta alokasinya, terutama sebagai tanggapan perusahaan dalam menghadapi lingkungan dan keadaan persaingan yang selalu berubah.

Keberhasilan usaha kecil menengah (UKM) dalam mendorong pembeli untuk melakukan keputusan pembelian merupakan implementasi dari konsep pemasaran yang berorientasi kepada konsumen, karena perusahaan inilah yang mampu menguasai pasar dalam jangka panjang. Di dalam pandangan konsep pemasaran, tujuan perusahaan dicapai melalui kepuasan konsumen. Kepuasan konsumen diperoleh setelah kebutuhan dan keinginan konsumen dipenuhi melalui kegiatan pemasaran yang terpadu. Dengan demikian ada 4 (empat) unsur pokok dalam konsep pemasaran, yaitu orientasi pada kebutuhan dan keinginan konsumen, kepuasan konsumen, kegiatan pemasaran yang terpadu,tujuan perusahaan.

Gunawan (2017) dalam penelitiannya menemukan bahwa strategi pemasaran (4P) berpengaruh nilai positif terhadap keputusan pembelian, yang berarti semakin baik nilai pengaruh dari strategi pemaran, maka semakin dapat meningkatkan tingkat 
JURNAL APLIKASI Manajemen \& Kewirausahaan MASS A RO

Volume 1, No. 1, Pebruari 2019

keputusan pembelian. Hasil penelitian dari Putri, Dio Gizky (2018) juga menemukan bahwa variabel produk, harga, lokasi dan promosi berpengaruh signifikan terhadap keputusan pembelian.

Tujuan yang ingin dicapai dalam artikel ini yaitu: pertama, mengetahui pengaruh strategi pemasaran terhadap kepuasan pembeli. Kedua, mengetahui pengaruh strategi pemasaran terhadap keputusan pembelian. Ketiga, mengetahui pengaruh kepuasan terhadap keputusan pembelian. Keempat, mengetahui pengaruh strategi pemasaran terhadap kepuasan dan keputusan pembelian.

\section{KERANGKA TEORI}

\section{Strategi Pemasaran}

Bauran pemasaran merupakan strategi yang dapat digunakan uoelah para pemilik usaha kecil menengah (UKM) untuk memenangkan persaingan pasar dan memperoleh pembeli sebanyak-banyaknya. Menurut Kotler (2012) menyatakan bahwa bauran bemasaran (marketing mix) merupakan seperangkat alat pemasaran yang digunakan perusahaan untuk terus menerus mempengaruhi konsumen untuk membeli produk atau jasa yang ditawarkan agar bisa mencapai tujuan perusahaannya di pasar sasaran. Menurut Agus Hermawan (2012) menjelaskan, "Marketing mix (bauran pemasaran) adalah empat komponen dalam yang terdiri dari 4P yaitu produk, harga, promosi, dan tempat ataupun distribusi. Kata lain marketing mix adalah kumpulan dari variabel yang dapat digunakan oleh perusahaan untuk dapat mempengaruhi tanggapan konsumen atau yang disebut dengan 4P.

Produk (Product) Pengertian produk menurut Philip Kotler dan Amstrong (2012) produk adalah segalah sesuatu yang dapat ditawarkan perusahaan ke pasar untuk mendapatkan perhatian, dibeli, digunakan, atau dikonsumsi yang dapat memuaskan keinginan dan kebutuhan. Produk meliputi objek secara fisik, jasa, variasi, kualitas, desain, fitur, merek, dan pengemasan. Keputusan tentang produk ini mencakup penentuan bentuk penawaran seacara fisik, mereknya, pembungkus, garansi dan servis sesudah penjualan.

Kotler dan Amstrong (2012) mendefinisikan harga (price) sebagai sejumlah uang yang dibebankan atas suatu produk atau jasa, atau jumlah dari nilai yang ditukar 
JURNAL APLIKASI Manajemen \& Kewirausahaan MASS A RO

Volume 1, No. 1, Pebruari 2019

konsumen atas manfaat-manfaat karena memiliki atau menggunakan produk atau jasa tersebut. Harga merupakan satu-satunya unsur bauran pemasaran yang mendatangkan pendapatan bagi perusahaan. Keputusan mengenai harga tidak mudah dilakukan, jika harga mahal akan dapat meningkatkan laba tetapi akan sulit dijangkau konsumen. Sebaliknya jika harga murah, pangsa pasar dapat melonjak, tetapi marjin kontribusi dan laba bersih yang diperoleh akan kecil (Tjiptono \& Chandra, 2012). Harga yang lebih murah bisa mengurangi risiko mencoba produk baru atau bisa pula dengan menaikkan nilai sebuah produk baru secara relatif dibandingkan produk lain yang sudah ada terlebih dahulu (Tjiptono \& Chandra, 2012).

Kotler dan Amstrong (2012) menjabarkan tempat (place) sebagai saluran distribusi yang meliputi kegiatan yang dilakukan oleh perusahaan untuk membuat suatu produk atau jasa, untuk digunakan atau dikonsumsi oleh konsumen. Saluran distribusi merupakan hal yang sangat penting, karena dengan adanya saluran distribusi akan memperlancar dan mempermudah penyampaian produk dari produsen kepada konsumen. Perusahaan hendaknya menentukan strategi dalam pemilihan jumlah dan bentuk saluran distribusi yang tepat untuk membuat produk tersedia bagi konsumen sasaran.

Kotler dan Amstrong (2012) mendefinisikan promosi (promotion) sebagai aktivitas untuk mengomunikasikan keunggulan produk dari pemasar untuk membujuk calon pembeli untuk membeli produk ataupun jasa yang ditawarkan. Promosi sebaiknya dilakukan terus menerus agar konsumen tetap mengingat produk/jasa tersebut. Promosi meliputi: periklanan, personal selling, promosi penjualan, public relations, dan direct \& online marketing (Tjiptono \& Chandra, 2012).

\section{Kepuasan Pembeli}

Kepuasan pembeli merupakan hal yang harus diperhatikan para pemilik UMK untuk menjadikan pembeli sebagai pelanggan yang setia mengkonsumsi produk atau jasa yang ditawarkan. Tjiptono \& Chandra (2012) mengemukakan bahwa kepuasan pembeli merupakan evaluasi purnabeli dimana alternatif yang dipilih sekurangkurangnya sama atau melampaui harapan, sedangkan ketidakpuasan memunculkan sejumlah resiko, komplain pelanggan dan reaksi pesaing, biasanya muncul apabila hasil tidak memenuhi harapan. Adapun menurut Kotler dan Keller (2012), kepuasan 
JURNAL APLIKASI Manajemen \& Kewirausahaan MA SS A RO

Volume 1, No. 1, Pebruari 2019

merupakan perasaan senang atau kecewa seseorang yang muncul karena membandingkan kinerja yang dipresepsikan produk (atau hasil) terhadap ekspektasi mereka”, jika kinerja (hasil) melebihi ekspektasi, maka pelanggan akan sangat puas atau senang.

\section{Keputusan Pembelian}

Keputusan pembelian konsumen merupakan tujauan dari para para pelaku bisnis dalam menyusun strategei pemasaran. Pranoto (2008) menjelaskan bahwa perilaku pengambilan keputusan oleh konsumen untuk melakukan pembelian produk atau jasa diawali dengan adanya kesadaran atas pemenuhan kebutuhan atau keinginan dan menyadari adanya masalah selanjutnya, maka konsumen akan melakukan beberapa tahap yang pada akhirnya sampai pada tahap evaluasi pasca pembelian. Menurut Swastha dan Handoko (2011) berpendapat bahwa lima peran individu dalam sebuah keputusan membeli, yaitu:

a) Pengambilan inisiatif (initiator): individu yang mempunyai inisiatif pembelian barang tertentu atau mempunyai kebutuhan atau keinginan tetapi tidak mempunyai wewenang untuk melakukan sendiri.

b) Orang yang mempengaruhi (influencer): individu yang mempengaruhi keputusan untuk membeli baik secara sengaja maupun tidak sengaja.

c) Pembuat keputusan (decider): individu yang memutuskan apakah akan membeli atau tidak, apa yang akan dibeli, bagaimana membelinya, kapan dan dimana membelinya.

d) Pembeli (buyer): individu yang telah melakukan pembelian yang sebenarnya.

e) Pemakai (user): individu yang menikmati atau memakai produk atau jasa yang dibeli.

\section{Kerangka Konseptual}

Kerangka pikir dalam peneltian ini dapat diuraikan sebagai berikut:

\section{Hubungan Stategi Pemasaran dengan Kepuasan Pembeli}

Rambat Lupiyoadi (2008:158) yang mengemukakan kepuasan merupakan tingkat perasaan di mana seseorang menyatakan hasil perbandingan atas kinerja produk/jasa yang diterima dan yang diharapkan. 
JURNAL APLIKASI Manajemen \& Kewirausahaan MASS A RO

Volume 1, No. 1, Pebruari 2019

\section{Hubungan Stategi Pemasaran dengan Keputusan Pembelian}

Salah satu penerapan strategi pemasaran yang biasanya dilakukan oleh para pemasar adalah Bauran Pemasaran. Bauran pemasaran ini terdiri dari beberapa faktor yang biasanya juga disebut dengan 4P, yaitu Product (Produk), Price (Harga), Promotion (Promosi), dan Place (Lokasi atau Saluran Distribusi)

\section{Hubungan Kepuasan dengan Keputusan Pembelian}

Kotler (2010) berpendapat bahwa kepuasan pembeli merupakan perasaan senang atau kecewa seorang yang merupakan hasil perbandingan dari persepsi kinerja produk dan harapannya. Ketika seorang calon pembeli mendapat rangsangan kepuasan dari inderanya maka akan timbul keinginan untuk membeli produk yang dilihat atau dirasakannya.

\section{Hubungan Stategi Pemasaran dengan Kepuasan dan Keputusan Pembelian}

Schiffman dan Kanuk (2008) mengemukakan bahwa keputusan pembelian adalah seleksi terhadap dua pilihan alternatif atau lebih konsumen pada pembelian. Setiap hari konsumen mengambil berbagai keputusan mengenai setiap aspek kehidupan seharihari. Tetapi, kadang mengambil keputusan ini tanpa memikirkan bagaimana keputusan ini. Pilihan alternatif harus tersedia bagi seseorang ketika mengambil keputusan (Schiffman dan Kanuk,2008). Proses keputusan pembelian dipengaruhi oleh rangsangan pemasaran. Rangsangan pemasaran yaitu bauran pemasaran yang dapat menimbulkan kepuasan dimana menurut Philip Kotler yang dikutip oleh Rambat Lupiyoadi (2008) "kepuasan merupakan tingkat perasaan di mana seseorang menyatakan hasil perbandingan atas kinerja produk/jasa yang diterima dan yang diharapkan". Kepuasan dan ketidakpuasan pelanggan akan suatu produk sebagai akhir dari suatu proses penjualan memberikan dampak tersendiri kepada perilaku pelanggan terhadap produk tersebut.

Adapun kerangka konseptual dari penelitian ini dapat dilihat pada gambar berikut. 
Gambar. 1 Kerangka Konseptual

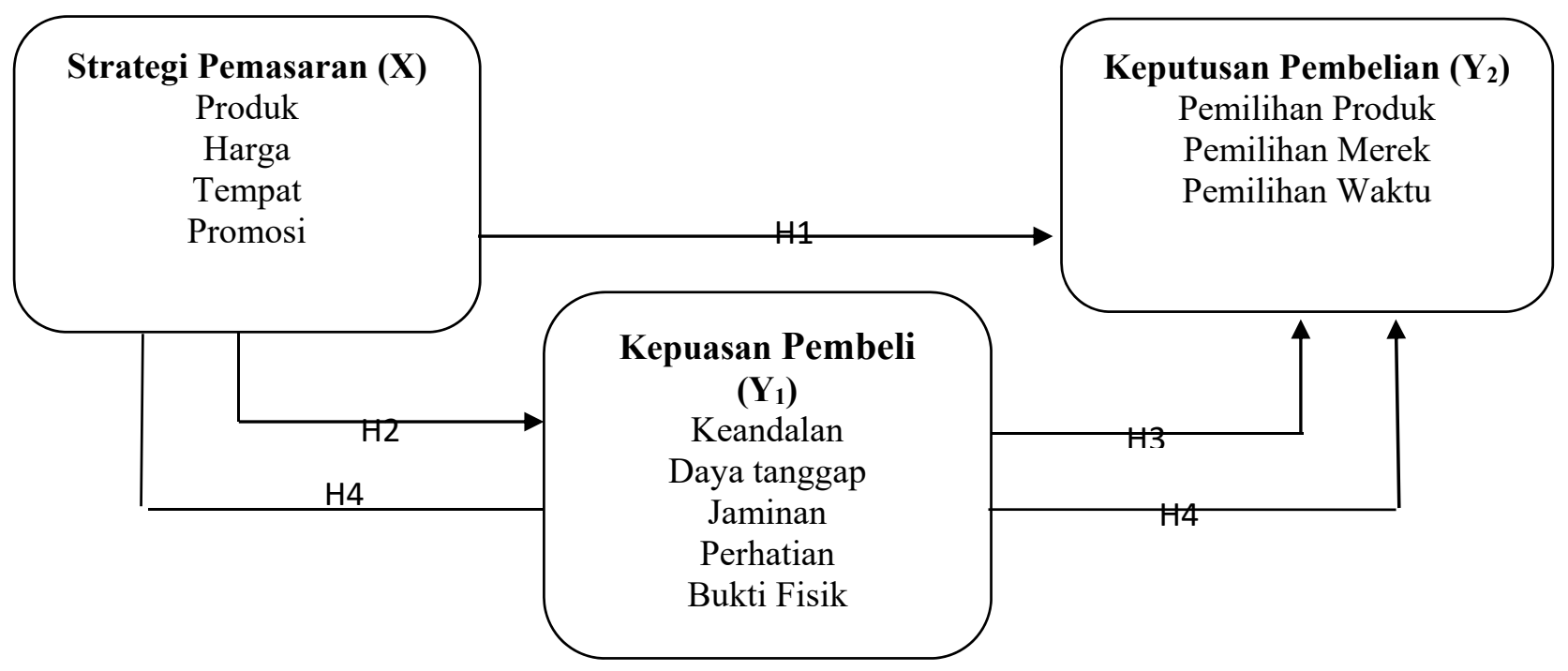

\section{A. Hipotesis}

1. Variabel strategi pemasaran berpengaruh positif dan signifikan terhadap kepuasan pembeli

2. Variabel strategi pemasaran berpengaruh positif dan signifikan terhadap keputusan pembelian

3. Variabel kepuasan pembeli berpengaruh positif dan signifikan terhadap keputusan pembelian

4. Variabel strategi pemasaran berpengaruh positif dan signifikan terhadap kepuasan pembeli dan keputusan pembelian

\section{METODE PENELITIAN}

Jenis penelitian ini yaitu penelitian survey yang pengambilan sampel dari sesuatu populasi dan menggunakan kuesioner sebagai alat pengumpulan data pokok. Oleh karena itu, dalam penelitian ini unit analisisnya adalah pembeli produk Usaha Kecil Menengah (UKM) 310 yang dilakukan pada tempat pemasaran produk dari 
JURNAL APLIKASI Manajemen \& Kewirausahaan MASS A RO

Volume 1, No. 1, Pebruari 2019

beberapa lokasi pameran UMKM Kota Makassar. Penelitian survei ini digunakan dengan maksud penjelasan (explanatory research) yaitu memberikan penjelasan hubungan kausal antara variabel-variabel melalui pengujian hipotesa dengan menggunakan metode analisis jalur (path) dan menggunkan bantuan software Smart PLS 2.3.8.

Terdapat beberapa alasan yang menjadi penyebab digunakan PLS dalam suatu penelitian. Dalam penelitian ini alasan-alasan tersebut yaitu: pertama, PLS (Partial Least Square) merupakan metode analisis data yang didasarkan asumsi sampel tidak harus besar, yaitu jumlah sampel kurang dari 100 bisa dilakukan analisis, dan residual distribution. Kedua, PLS (Partial Least Square) dapat digunakan untuk menganalisis teori yang masih dikatakan lemah, karena PLS (Partial Least Square) dapat digunakan untuk prediksi. Ketiga, PLS (Partial Least Square) memungkinkan algoritma dengan menggunakan analisis series ordinary least square (OLS) sehingga diperoleh efisiensi perhitungan olgaritma (Ghozali, 2006). Keempat, pada pendekatan PLS, diasumsikan bahwa semua ukuran variance dapat digunakan untuk menjelaskan. Populasi dan sampel dalam penelitian sebanyak 100 responden.

\section{Analisis Data}

Analisis data dalam penelitian ini dengan menggunakan menggunakan bantuan software PLS 3.2.8. PLS dapat digunakan pada setiap jenis skala data (nominal, ordinal, interval, dan rasio) serta syarat asumsi yang lebih fleksibel. PLS juga digunakan untuk mengukur hubungan setiap indikator dengan konstruknya. Selain itu, dalam PLS dapat dilakukan uji bootsrapping terhadap struktural model untuk melihat nilai koefisen path, $\mathrm{t}$ statistik serta $\mathrm{p}$ value yang harus lebih rendah daripada 0.005 untuk menentukan tingkat signifikansi dari sebuah hipotesis.

\section{HASIL DAN PEMBAHASAN}

\section{Uji Validitas dan Reabilitas}

Uji validitas konstruk penyusun variabel dalam penelitian ini dapat dilihat dari hasil bootstrapping aplikasi Smart PLS 3.2.8 dengan nilai outer loading. Syarat nilai outer loading yang valid yakni memperlihatkan seluruh outer loading dimensi variabel 
JURNAL APLIKASI Manajemen \& Kewirausahaan MA SS A RO

Volume 1, No. 1, Pebruari 2019

memiliki nilai loading $>0,5$. Adapun outer loading untuk konstruk penyusun variabel dalam penelitian ini dapat dilihat pada tabel berikut.

Tabel 1. Outer Loading

\begin{tabular}{|c|c|c|c|c|c|}
\hline & Sampel Astif (0) & Rata-rata Sem.. & Standar Devias... & T Statistik (| $0 / . .$. & P Values \\
\hline$X 1,1,1<=$ Strategi Pemasaran & 0.852 & 0.552 & 0.089 & 28.939 & 0.000 \\
\hline X1.1.2. e- Strategi Pemasaran & 0.847 & 0.847 & 0.033 & 25.707 & 0.000 \\
\hline X1.1.3. \&-Strategi Pemasaran & 0.795 & 0.794 & 0.044 & 18.114 & 0.000 \\
\hline X1.2.1 <- Strategi Pemasaran & 0.665 & 0.666 & 0.060 & 11.000 & 0.000 \\
\hline X1.2.2 <- Strategi Pemasaran & 0.679 & 0.679 & 0.061 & 11.048 & 0.000 \\
\hline$X 1.2 .3<-$ Strategi Pemasaran & 0.618 & 0.620 & 0.070 & 8.832 & 0.000 \\
\hline X1.3.1 <-Strategi Pemasaran & 0.656 & 0.647 & 0.067 & 9.803 & 0.000 \\
\hline$X 1.3 .2<-$ Strategi Pemasaran & 0.601 & 0.593 & 0.054 & 7.167 & 0.000 \\
\hline$X 1,4.1<-$ Strategi Pemasaran & 0.587 & 0.579 & 0.074 & 7,902 & 0.000 \\
\hline $\mathrm{X} 1,4.2<$ - Strategi Pemasaran & 0.690 & 0.688 & 0.061 & 11,360 & 0.000 \\
\hline $\mathrm{X} 1.4 .3<-$ Strategi Pemasaran & 0.511 & 0.497 & 0.108 & 4.721 & 0.000 \\
\hline Y $1,1,1<-$ Kepuasan Pembeli & 0.683 & 0.678 & 0.057 & 11.981 & 0.000 \\
\hline V1.1.2 <- Kepuasan Pembeli & 0.700 & 0.693 & 0.069 & 10.121 & 0.000 \\
\hline Y1.2.1 <- Kepuasan Pembeli & 0.747 & 0.743 & 0.060 & 12473 & 0.000 \\
\hline V1.2.2 <- Kepuasan Pembeli & 0.605 & 0.602 & 0.078 & 7.742 & 0.000 \\
\hline Y1.3.1 <-Kepuasan Pembeli & 0.694 & 0.679 & 0.067 & 10.282 & 0.000 \\
\hline V1.3.2 <- Kepuasan Pembeli & 0.600 & 0.595 & 0.078 & 7.57 & 0.000 \\
\hline VI.4.1 <-Kepuasan Pembeli & 0.820 & 0.818 & 0.040 & 20.633 & 0.000 \\
\hline V1.4.2 <- Kepuasan Pembeli & 0.578 & 0.577 & 0.094 & $6: 840$ & 0.000 \\
\hline V1.5.1 <- Kepuasan Pembeli & 0.783 & 0.783 & 0.042 & 18.746 & 0.000 \\
\hline V1.5.2 <- Kepuasan Pembeli & 0.579 & 0.578 & 0.071 & 8.202 & 0.000 \\
\hline V.1.1 <- Keputusan Pembel_ & 0.847 & 0.852 & 0.032 & 26.812 & 0.000 \\
\hline V.1.2 <- Keputusan Pembel- & 0.922 & 0.924 & 0.016 & 58.881 & 0.000 \\
\hline V2.2.1 <- Keputusan Pembel_ & 0.890 & 0.891 & 0.026 & 33.641 & 0.000 \\
\hline V.2.2 <- Keputusan Pembel & 0.707 & 0.702 & 0.061 & 11.58 & 0.000 \\
\hline V2.3.1 <- Keputusan Pembel- & 0.855 & 0.854 & 0.039 & 21.847 & 0.000 \\
\hline V2.3.2 «- Keputusan Pembel_ & 0.632 & 0.623 & 0.072 & $8.7 \%$ & 0.000 \\
\hline
\end{tabular}

Sumber: Olah Data Smart PLS (2018) 
Berdasarkan tabel nilai outer loading di atas dapat dilihat jika keseluruhan konstruk penyusun variabel telah memiliki nilai loading diatas 0,5 sehingga semua konstruk penyusun dari ketiga variabel yang diteliti dinyatakan valid dan dapat diteliti lebih lanjut.

Selanjutnya uji reliablitas dapat dilihat dari nilai Crombach's alpha dan nilai composite reliability. Untuk dapat dikatakan suatu item pernyataan reliabel, maka nilai Cronbach's alpha harus $>0,6$ dan nilai composite reliability harus $>0,7$. Adapun uji reabilitas pada penelitan ini dapat dilihat pada tabel berikut.

Tabel 2. Uji Reabilitas

\begin{tabular}{|l|c|c|c|}
\hline \multicolumn{1}{|c|}{ Variabel } & Cronbach Alfa & Rebilitas Composite & Keterangan \\
\hline Strategi Pemasaran & 0.886 & 0.907 & Reliabel \\
\hline Kepuasan Pembeli & 0.870 & 0.896 & Reliabel \\
\hline nKeputusan Pembelian & 0.871 & 0.921 & Reliabel \\
\hline
\end{tabular}

Sumber: Smart PLS 3.2.8

Berdasarkan tabel 3 diatas dapat dilihat bahwa nilai Cronbach's alpha dari ketiga variabel $>0,6$. Adapun nilai composite reliability dari ketiga variabel yang diteliti telah lebih besar daripada 0,7 sehingga variabel penyusun dalam penelitian ini telah dinyatakan reliable.

\section{Pengujian Hipotesis}

Pengujian hipotesis dari penelitian ini dapat diketahui dengan melakukan perhitungan bootstrapping yang menunjukkan nilai koefisien jalur baik berupa pengaruh langsung dan pengaruh tidak langsug yang disajikan pada tabel berikut.

Tabel 3. Nilai Koefisen Jalur

\begin{tabular}{|l|c|c|c|c|}
\hline \multicolumn{1}{|c|}{ Hipotesis } & Koefisien & $\begin{array}{c}\text { T } \\
\text { Statistik }\end{array}$ & $\begin{array}{c}\mathbf{P} \\
\text { Value }\end{array}$ & Keterangan \\
\hline Strategi Pemasaran-> Kepuasan Pembeli & 0.818 & 26.300 & 0.000 & Diterima \\
\hline Strategi Pemasaran-> Keputusan Pembelian & 0.535 & 4.832 & 0.000 & Diterima \\
\hline Kepuasan Pembeli-> Keputusan Pembelian & 0.278 & 2.536 & 0.019 & Diterima \\
\hline $\begin{array}{l}\text { Strategi Pemasaran-> Kepuasan Pembeli-> } \\
\text { Keputusan Pembelian }\end{array}$ & 0.228 & 2.292 & 0.022 & Diterima \\
\hline
\end{tabular}

Sumber: Olah Data Smart PLS (2018) 
Berdasarkan tabel 3 diatas dapat diketahui bahwa:

1. Strategi pemasaran berpengaruh positif terhadap kepuasan yang ditunjukkan dengan nilai koefisien sebesar 0.818 dan t statisatik sebesar 23.3 serta P Value 0.000 yang menunjukkan pengaruh signifikan terhadap kepuasan pembeli. Hal tersebutt tidak terlepas dari kualitas produk serta bentuk kemasarn produk UMK 310 yang memuaskan serta kemasan yang unik, harga terjangkau yang ditawarkan sesuai dengan nilai yang diharapkan, lokasi pameran yang mudah dijangkau, serta promosi yang dilakukan pada lokasi pameran berbeda dengan kondisi ketika konsumen membeli produk di toko besar ataupun media sosial online telah memberi kesan yang memuaskan pada para pembeli.

Hasil penelitian ini sesuai dengan pendapat dari Philip Kotler yang dikutip oleh Rambat Lupiyoadi (2008) yang mengemukakan kepuasan merupakan tingkat perasaan di mana seseorang menyatakan hasil perbandingan atas kinerja produk/jasa yang diterima dan yang diharapkan. Adapun dalam penelitian ini para pembeli merasa puas dengan produk yang ditawarkan oleh UKM 310 dengan strategi pemasaran yang diterapkan dalam acara pameran.

Hasil penelitian dari Faizul, A. (2008) menunjukkan bahwa strategi pemasaran yang terdiri dari produk, harga, promosi dan lokasi berpengaruh sangat siginifikan terhadap kepuasan pelanggan. Dalam penelitian ini strategi pemasaran yang dilakukan oleh pemilik UKM 310 telah memberi kepuasan terhadap pembeli sehingga hasil dari penelitian ini mendukung hasil penelitian sebelumnya.

2. Strategi pemasaran berpengaruh positif terhadap keputusan pembelian yang ditunjukkan dengan nilai koefisien sebesar 0.535 dan t statisatik sebesar 4.83 serta P Value 0.000 yang menunjukkan pengaruh signifikan terhadap keputusan pembelian. Hal tersebut tidak terlepas dari kualitas produk dan kemasan yang menarik untuk dikonsumsi ataupun dijadikan oleh-oleh untuk keluarga dan teman, harganya pun sesuai dengan nilai yang diharapkan. Informasi dari mulut ke mulut pun sudah mulai memberi dampak bagi calon 
pembeli untuk melakukan pembelian produk UKM 310. Adapun lokasi penjualan di pameran memberi pengaruh terhadap keputusan pembelian karena lokasi pamaeran yang menarik serta tampilan tempat penjualan yang unik membuat calon pembeli tertarik untuk singgah membeli produk UKM 310.

Hasil penelitian ini sejalan dengan pendapat dari Schiffman dan Kanuk (2008) yang mengemukakan bahwa pemilik usaha dituntut untuk mempertimbangkani konsumen sebagai salah satui faktori terpenting dalami pasar, karenai dengan memperhatikani kebutuhan dani keinginani konsumeni, perusahaan dapat memenangkani persaingani pasar. Jika faktor tersebut telah dipertimbangkan oleh perusahaan, maka dapat memberikan manfaat bagi perusahaan salah satunya konsumen akan membuat keputusan pembelian produk. Salah satu dari faktor tersebut biasanya ada yang lebih dominan dalam mempengaruhi keputusan pembelian. keputusan pembelian adalah suatu proses dimana konsumen melakukan penilaian terhadap berbagai alternatif pilihan dan memilih salah satu atau lebih alternatif yang diperlukan berdasarkan pertimbangan tertentu dalam pembelian. Adapun strategi lokasi pemasaran yang dilakukan pada kegiatan pameran ternyata mampu membuat calon pembeli tertarik untuk melakukan pembelian produk UKM 310.

Hasil penelitian dari Abdul, G. (2015) menemukan bahwa strategi pemasaran yang meliputi produk, harga, promosi dan saluran distribusi berpengaruh positif dan signifikan terhadap keputusan pembelian sehingga hasil penelitian ini mendukung hasil penelitian sebelumnya.

3. Kepuasan berpengaruh positif terhadap keputusan pembelian yang ditunjukkan dengan nilai koefisien sebesar 0.278 dan t statisatik sebesar 2.536 serta P Value 0.019 yang menunjukkan pengaruh signifikan terhadap keputusan pembelian. Para pembeli umumnya puas akan rasa dari produk ataupun tampilan kreatif dari kerajinan tangan UMK 310. Secara umum kepuasan yang terbentuk secara umum berasal dari produk, lokasi, waktu pemasaran. Pemilihan kemasan yang unik dan kreatif serta pemilihan waktu penjualan yang tepat karena pameran biasa dilakukan pada akhir pekan ataupun malam hari. Hal tersebut mendukung keputusan pembelian produk UKM 310. 
Kotler (2010) berpendapat bahwa kepuasan pembeli merupakan perasaan senang atau kecewa seorang yang merupakan hasil perbandingan dari persepsi kinerja produk dan harapannya. Ketika seorang calon pembeli mendapat rangsangan kepuasan dari inderanya maka akan timbul keinginan untuk membeli produk yang dilihat atau dirasakannya.

4. Strategi pemasaran berpengaruh positif terhadap keputusan pembelian yang ditunjukkan dengan nilai koefisien sebesar 0.535 dan t statisatik sebesar 4.83 serta P Value 0.000 yang menunjukkan pengaruh signifikan terhadap keputusan pembelian. Strategi pemasaran yang meliputi produk yang dengan rasa yang nikmat dan tampilan yang menarik, harga yang terjangkau dan sesuai nilai, promosi yang dilakukan langsung pada tempat pameran Koperasi dan UMKM ternyata dapat membuat kepuasan tersendiri dari para calon pembeli ataupun pelanggan untuk mengambil keputusan pembelian produk UMK 310 .

Schiffman dan Kanuk (2008) mengemukakan bahwa keputusan pembelian adalah seleksi terhadap dua pilihan alternatif atau lebih konsumen pada pembelian. Setiap hari konsumen mengambil berbagai keputusan mengenai setiap aspek kehidupan sehari-hari. Tetapi, kadang mengambil keputusan ini tanpa memikirkan bagaimana keputusan ini. Pilihan alternatif harus tersedia bagi seseorang ketika mengambil keputusan (Schiffman dan Kanuk,2008:485). Proses keputusan pembelian dipengaruhi oleh rangsangan pemasaran. Rangsangan pemasaran yaitu bauran pemasaran yang dapat menimbulkan kepuasan dimana menurut Philip Kotler yang dikutip oleh Rambat Lupiyoadi (2008:158) "kepuasan merupakan tingkat perasaan di mana seseorang menyatakan hasil perbandingan atas kinerja produk/jasa yang diterima dan yang diharapkan". Kepuasan dan ketidakpuasan pelanggan akan suatu produk sebagai akhir dari suatu proses penjualan memberikan dampak tersendiri kepada perilaku pelanggan terhadap produk tersebut. Kepuasan konsumen dapat tercapai dengan adanya kegiatan pemasaran, karena tujuan pemasaran adalah memenuhi dan memuaskan kebutuhan konsumen. Kepuasan konsumen juga dapat ditunjukkan melalui sikap pembelian. 
Hasil penelitian dari Setiawan, M. (2013). Menemukan bahwa keputusan pembelian dapat dipengaruhi oleh bauran pemasaran dan kepuasan pelanggan sehingga hasil penelitian ini mendukung hasil penelitian sebelumnya.

\section{KESIMPULAN DAN SARAN}

Berdasarkan hasil penelitian, kesimpulan untuk penelitian ini yakni secara parsial strategi pemasaran memiliki pengaruh positif dan signifikan terhadap kepuasan dan keputusan pembelian produk UKM 310. Disamping itu kepuasan berpengaruh positif dan signifikan terhadap keputusan pembelian produk UKM 310. Adapun secara tidak langsung, strategi pemasaran berpengaruh positif dan signifikan terhadap keputusan pembelian produk UKM 310 jika dimediasi oleh kepuasan pembeli.

Saran dari kesimpulan penelitian ini yakni jika strategi pemasaran yang sudah bagus di mata konsumen, hendaknya tetap dipertahankan agar tidak mengalami penurunan. Mengenai kepuasan konsumen, hendaknya UKM 310 dapat mempertahankan konsumen yang sudah puas dalam menggunakan produk yang diproduksi dengan sebaik mungkin seperti sekarang dan terus melakukan inovasi produk yang dapat memuaskan pembeli. Mengenai keputusan pembelian, variabel keputusan pembelian mendapatkan poin yang baik karena banyaknya konsumen yang membeli produk yang dipasarkan sehingga UKM 310 harus mempertahankan dan meningkatkan keputusan pembelian konsumen. Alasannya agar UKM 310 dapat mengungguli meningkatkan jumlah pembeli hingga membentuk pelanggan setia.

\section{DAFTAR PUSTAKA}

Abdul, G. (2015). Pengaruh Bauran Pemasaran Terhadap Keputusan Pembelian Baju Batik Cv. Danaris Home Industry Di Pemalang. Fakultas Ekonomi \& Bisnis Universitas Dian Nuswantoro Semarang

Agus Hermawan. (2012). Komunikasi Pemasaran. Jakarta, Erlangga

Assauri, Sofjan. (2013). Manajemen Pemasaran. Jakarta : Rajawali Pers. 
Bambang Pranoto, (2008), "Pengaruh harga dan kualitas produk terhadap keputusan konsumen membeli kendaraan bermotor", Jurnal Ilmiah Indonesia, Vol.1 (no.2): 40-46, Jakarta.

Basu Swastha, Hani Handoko. (2011). Manajemen Pemasaran-Analisis Perilaku. Konsumen. Yogyakarta : BPFE.

Faizul, A. (2008). Pengaruh Strategi Bauran Pemasaran Ritel Terhadap Kepuasan dan Hubungannya dengan Loyalitas Pelanggan Plaza Medan Fair di Medan. (Master's thesis).

G. Leon, Schiffman dan Lazar L Kanuk. (2008). Perilaku Konsumen. Edisi Ketujuh.

Ghozali, Imam. (2006). Aplikasi Analisis Multivariate dengan Program SPSS (Edisi Ke 4). Semarang:Badan Penerbit Universitas Diponegoro

Gunawan, A. (2017). Analisis Bauran Pemasaran Dan Pengaruh Citra Produk Shuttlecock Terhadap Keputusan Pembelian Yang Berdampak Pada Kepuasan Konsumen (Di Perusahaan Shuttlecock "LIYA”). Universitas Muhammadiyah Surakarta

Husein Umar, (2003), Metodologi Penelitian Untuk Skripsi dan Tesis Bisnis,Jakarta. : PT. Gramedia Pustaka

Kotler dan Amstrong (2012). Manajemen Pemasaran.. Jakarta: Erlangga.

Kotler, P., \& Keller, K. L. (2010). Manajemen Pemasaran. Jakarta: Erlangga.

Padhil, A., Saleh, A., Nusran, M., Ismail, H., \& Aidel, A. (2018). Strategi Pemasaran Kue Bagea Sebagai Kue Khas Kota Palopo Dengan Menggunakan Analisis Swot Pada UKM Multi Kue Kota Palopo. Journal of Industrial Engineering Management, 3(2), 15-23.

Putri, Dio Gizky (2018) Analisis Pengaruh Bauran Pemasaran (Marketing Mix) Terhadap Keputusan Pembelian dan Kepuasan Konsumen (Studi Kasus di UKM Keripik Apel UD Ramayana Agro Mandiri Batu). Sarjana thesis, Universitas Brawijaya.

Rambat Lupiyoadi dan A. Hamdani (2008). Bauran Pemasaran Barang Vs Jasa. Jakarta. Salemba Empat.

Setiawan, M. (2013). Analisis Bauran Pemasaran Dalam Kaitannya Dengan Kepuasan Konsumen Dan Pengaruhnya Terhadap Keputusan Pembelian (Studi Kasus Penjualan Mebel Pada PT. Multi Manunggal). Jurnal Sekolah Tinggi Ilmu Ekonomi Kesatuan

Tjiptono, Fandy dan Gregorius Chandra. (2012). Pemasaran Strategik. Yogyakarta,. ANDI. 